Article

\title{
Influence of Atmospheric Aerosols on Evapotranspiration over a Semiarid Region in Northeast Brazil
}

\author{
Antonio José Steidle Neto ${ }^{1}$, Daniela de Carvalho Lopes ${ }^{1}$ \\ ${ }^{1}$ Departamento de Ciências Agrárias, Universidade Federal de São João del-Rei, Campus Sete \\ Lagoas, Sete Lagoas, MG, Brasil.
}

Received: 10 October 2017 - Accepted: 22 March 2018

\begin{abstract}
The knowledge of atmospheric aerosol characteristics at regional and local scales, their temporal changes and interrelations with meteorological variables are of great importance because can modify the global radiative energy balance. This study was carried out to evaluate the influence of aerosols on evapotranspiration over a semiarid region in Northeast Brazil. Aerosol optical depth, global solar radiation, air temperature, air relative humidity, and wind speed were measured in the Research National Center of Semiarid, located at Petrolina, Pernambuco State, Brazil, along two consecutive years. A multivariate model was calibrated and validated for estimating the global solar radiation $\left(R_{\text {global }}\right)$ based on the aerosol optical depths $(A O D)$ and extraterrestrial solar radiation $\left(R_{0}\right)$. Estimates of the reference evapotranspiration $\left(E T_{0}\right)$ were obtained by using the FAO standard Penman-Monteith method. Results confirmed that larger aerosol optical depth tends to decrease both $R_{\text {global }}$ and $E T_{0}$. Otherwise, ticker aerosol optical depth tends to absorb less radiation, increasing the $E T_{0}$. For the semiarid region in Northeast Brazil, most of $E T_{0}$ deviations were smaller than $\pm 4 \%$. However, higher deviations were also observed, contributing jointly to around $30 \%$, which may result in relevant consequences on the irrigation management, water balance, agroclimatic zoning, among other activities based on the $E T_{0}$ estimates.
\end{abstract}

Keywords: solar radiation, modeling, aerosol radiative forcing, aerosol optical depth.

\section{Influência de Aerossóis Atmosféricos na Evapotranspiração de uma Região Semiárida no Nordeste do Brasil}

\begin{abstract}
Resumo
O conhecimento das características de aerossóis atmosféricos nas escalas local e regional, suas modificações temporais e inter-relações com as variáveis meteorológicas são de grande importância, pois podem modificar o balanço de energia radiativa global. Esse estudo foi realizado para avaliar a influência de aerossóis na evapotranspiração de uma região semiárida no Nordeste do Brasil. Profundidade ótica de aerossol, radiação solar global, temperatura, umidade e velocidade do ar foram medidas na Embrapa Semiárido, localizada em Petrolina, PE, durante dois anos consecutivos. Um modelo multivariado foi calibrado e validado para estimar a radiação solar global $\left(R_{\text {global }}\right)$ com base em profundidades óticas de aerossóis $(A O D)$ e radiação solar extraterrestre $\left(R_{0}\right)$. Estimativas da evapotranspiração de referência $\left(E T_{0}\right)$ foram obtidas pelo método de Penman-Monteith FAO. Os resultados confirmaram que maiores profundidades óticas de aerossóis tendem a diminuir a $R_{\text {global }}$ e $E T_{0}$. Ao contrário, menores profundidades óticas de aerossóis tendem a absorver menos radiação, aumentando a $E T_{0}$. Para a região semiárida no Nordeste, a maioria dos desvios de $E T_{0}$ foi menor que $\pm 4 \%$. Entretanto, maiores desvios foram também observados, contribuindo em torno de $30 \%$, o que pode resultar em consequências relevantes no manejo de irrigação, balanço hídrico, zoneamento agroclimático, dentre outras atividades baseadas em estimativas de $E T_{0}$.
\end{abstract}

Palavras-chave: radiação solar, modelagem, forçante radiativa de aerossol, profundidade ótica de aerossol.

${ }^{1}$ Corresponding author: Antonio José Steidle Neto, antonio@ufsj.edu.br. 


\section{Introduction}

Atmospheric aerosols are particles constituted by soil dust, soot from biomass burning, volcanic ash, sea salt, biogenic material (pollen, fungi spores, leaf residues), among other, which are suspended in the terrestrial atmosphere (Martin et al., 2010; Paixão, 2011).

The knowledge of aerosol characteristics at regional and local scales, their temporal changes and interrelations with solar radiation, are of great importance for atmospheric research (Che et al., 2011; Kumar et al., 2013; Murthy et al., 2014; Sivakumar et al., 2010; Wang et al., 2010). Atmospheric aerosols influence directly and indirectly the weather and climate in the earth through their ability to scatter and absorb incoming solar radiation, although the magnitude of this influence remains uncertain (IPCC, 2007; Krzyścin and Puchalski, 1998; Kumar et al., 2013). As direct consequence can be verified reducing the total amount of solar radiation reaching the earth surface (Paixão, 2011; Trenberth et al., 2009) and increasing the diffuse fraction of this radiation (Liepert and Tegen, 2002).

The main parameter to assess the radiative forcing effect of aerosols on the earth climate is the aerosol optical depth, which is an indicator of the aerosol loading in the entire vertical column of air from the earth surface to the top of the atmosphere (Kumar et al., 2013).

The AErosol RObotic NETwork (AERONET) provides continuous time series of atmospheric aerosol measurements with a very high temporal resolution (Holben et al., 1998, 2001). AERONET is a ground-based remote sensing network of sun photometers, established and maintained by the National Aeronautics and Space Administration (NASA), set up with an international cooperation to characterize global aerosol optical properties. Although its continuous expansion, with more than 1,000 stations world-wide, AERONET have approximately 52 stations in the Brazilian territory. From these, 32 stations supply data with quality assured (processing level 2.0), pre- and post-field calibration applied, automatically cloud cleared, and manually inspected. Despite the number of stations is not small, there are some data lacking that limit scientific studies.

With great importance for agricultural and urban planning, irrigation managing, regional water balance studies, and agroclimatic zoning (Steidle Neto et al., 2015), evapotranspiration is one of the variables affected by the atmospheric aerosol presence due to changes in the global solar radiation on earth surface. Some observational studies have been attempted to evaluate the aerosol direct effects on the latent heat flux at site levels (Murthy et al., 2014; Steiner et al., 2013; Wang et al., 2008). These researches have shown that atmospheric aerosols generally reduce the energy available for evapotranspiration. Therefore, analyzing the influence of aerosols on surface energy budgets can improve the understanding of regional and local climate. In this context, the present study was carried out to evaluate the influence of atmospheric aerosols on evapotranspiration over a semiarid region in Northeast Brazil.

\section{Material and Methods}

\subsection{Database}

The study area is located at the Petrolina city, Pernambuco State, in Northeast Brazil. According to the Köppen classification, the climate is hot semiarid (BSh) with rainy period between spring and summer (Alvares et al., 2013). This region is characterized by scarce and irregular rainfall. Further, summer is humid and hot, while winter is mild and dry. The predominant vegetation is the Caatinga, composed by scattered shrub species with small and medium sizes.

The aerosol optical depths were obtained from a high precision multispectral sun photometer (model CE318-T, Cimel Electronique, Paris, France) belonging to AERONET and installed at the Semiarid Research National Center of the Brazilian Agricultural Research Corporation (Empresa Brasileira de Pesquisa Agropecuária - EMBRAPA), located at Petrolina (09 04'08”S, $40^{\circ} 19^{\prime} 11^{\prime \prime} \mathrm{W}$, and $387 \mathrm{~m}$ elevation). This equipment measures sun irradiance in eight distinct wavelengths (340, $380,440,500,670,870,940$, and $1020 \mathrm{~nm}$ ) by using passband spectral filters placed in a step motor driven wheel coupled to the photometer sensor. The equipment also features a sun tracking system and a satellite data transmitter. The aerosol optical depth was calculated by the BeerLambert-Bouguer law, based on the spectral extinction of the direct solar radiation at each wavelength. The solar radiation attenuation due to Rayleigh scattering, absorption by ozone and gaseous pollutants $\left(\mathrm{NO}_{2}, \mathrm{CO}_{2}\right.$, and $\mathrm{CH}_{4}$ ) was estimated and subtracted from the total optical depth in order to isolate the aerosol effects (Holben et al., 1998).

Daily aerosol optical depths were checked for consistency and quality by AERONET, as well as calibrated and cloud-screened to remove signals contaminated by clouds (processing level 2.0). Considering only data from this processing level, the historical aerosol series presents many days on which there is no information with assured quality. The data acquisition in the Petrolina station started in 2004 and finished in 2014, excluding the years of 2006, 2010, and 2011, in which data was not acquired. In this study, a thorough analysis of the historical series was performed aiming at accounting the number of days with data resulted from processing level 2.0 for each year. Based on the results of this analysis, the years of 2013 and 2014 were selected since they presented the larger percentiles of 
data ( $70.7 \%$ and $62.7 \%$, respectively), totalizing 487 days with $A O D$ data.

Meteorological data (air temperature, air relative humidity, global solar radiation, and wind speed) were obtained from an automatic meteorological station located at the same place of the AERONET photometer, however belonging to the Brazilian network of stations from the National Organization System of Environmental Data (Sistema Nacional de Organização de Dados Ambientais SONDA) of the Brazilian National Institute for Space Research (Instituto Nacional de Pesquisas Espaciais INPE). Despite this historical series also contains data from 2013-2014, only the common data between the AERONET and SONDA series were used with the purpose of matching the information bases. Additionally, daily averages were calculated for air temperature, air relative humidity, and wind speed since these data were measured in one-minute interval. Further, the global solar radiation was integrated on a daily scale.

\subsection{Calibration and validation of a model for estimating the global solar radiation}

A multivariate model was developed, previously to evaluate the influence of the aerosols on the evapotranspiration, for estimating the global solar radiation on terrestrial surface $\left(R_{\text {global }}\right)$ as function of the aerosol optical depths $(A O D)$ and the extraterrestrial solar radiation $\left(R_{0}\right)$. The $A O D$ values at $340 \mathrm{~nm}$ did not were used during the modeling due to the partial absence of these data for the 2013-2014 biennium. The $R_{0}$ was estimated in daily scale following the procedures and equations described by Allen et al. (1998), considering the latitude of the meteorological station of the SONDA network and the Julian day of each data of the historical series.

The proposed model was calibrated and validated by applying the minimum partial least squares algorithm presented by Wold et al. (2001), which was implemented in the SCILAB software (Scilab Enterprises, Versailles, France). This method is based on latent variables (factors) defined as linear combinations of the original independent variables $\left(A O D\right.$ and $\left.R_{0}\right)$ and the dependent one $\left(R_{\text {global }}\right)$. The latent variables were calculated by iterative methods in such a way that they were oriented along the directions of maximal covariance between the response and the independent variables. Thus, the latent variables are not directly measurable or observable, but are used in statistical modeling techniques as mathematical functions or algorithms that represent essential information of the original variables.

Considering the total number of data that matched between AERONET and SONDA networks for the 20132014 biennium, 75\% were used for calibration with crossvalidation and $25 \%$ for the external validation, corresponding to 365 and 122 daily data, respectively. The calibration with cross-validation was performed according to the leave-group-out technique, in which for each number of latent variables (varying from one to ten) considered during the modelling process, the calibration dataset was divided in three groups containing representative data samples, and models from reduced datasets were developed with one of the groups deleted. Then, the capability of each model to predict responses for the omitted group was checked by computing the sum of squares of the differences between the predicted response values and the measured ones. This procedure was repeated until every group was left out once, when the variance of all prediction residuals was estimated and the best model was selected. A mean prediction residual was calculated considering the models associated with each number of latent variables. The final model and the number of latent variables used to estimate the response variable $\left(R_{\text {global }}\right)$ were those with the lower mean prediction residual. External validation was done by predicting independent samples, not related with samples included in the calibration and cross-validation sets, with the selected model. The external validation procedure was important for evaluating the model performance considering independent data from those applied in the calibration with cross-validation (Agelet and Hurburgh Jr., 2014).

The optimal number of latent variables was determined following recommendations of Jha (2010) and Wold et al. (2001), considering the minimum root mean square error and the maximum coefficient of correlation of the cross-validation. The predictive capacity of the adjusted model in the context of external validation was evaluated by the mean absolute error, mean relative error and mean bias error, following the suggested by Forina et al. (2004) and Yang et al. (2014).

\subsection{Influence of the aerosol optical depth on the evapotranspiration}

The reference evapotranspiration $\left(E T_{0}\right)$ values were estimated on a daily scale from the meteorological data of air temperature, air relative humidity, global solar radiation, and wind speed by using the standard FAO PenmanMonteith method (Allen et al., 1998). Following recommendations of Allen (2013), wind speed was limited to above $0.5 \mathrm{~m} \mathrm{~s}^{-1}$. This is a recommendation taking account the effects of boundary layer instability and buoyancy of air in promoting exchange of vapor at the surface when the wind speed is small. Thus, the wind speed limitation in the $E T_{0}$ equation improves the estimation accuracy under the conditions of very low wind speed.

Previously to the $E T_{0}$ estimations, a consistency analysis was accomplished to the meteorological data by using electronic spreadsheet functions, aiming at removing all inconsistent data. Also, visual analysis of graphs relating the variables to time was employed as a complementary tool. 
The evaluation of the influence of aerosol optical depth on the $E T_{0}$ estimations was accomplished considering 17 reference values (scenarios) between 3.8 and $7.8 \mathrm{~mm} \mathrm{~d}^{-1}$ with increments of approximately $0.25 \mathrm{~mm} \mathrm{~d}^{-1}$. Each scenario corresponds to a typical value of reference evapotranspiration that can occur in the studied area. This range was determined based on the minimum and maximum $E T_{0}$ values estimated when considering the 20132014 biennium.

Simulations were performed for each scenario, maintaining constant the meteorological variables and the extraterrestrial solar radiation, while varying the $A O D$ values by using the measured values of the external validation dataset. Thus, new $E T_{0}$ values were calculated from the $R_{\text {global }}$ values estimated with the multivariate model and the different $A O D$ values, evidencing the effects of the atmospheric aerosols. Additionally, the minimum and maximum deviations associated with each $E T_{0}$ scenario were computed when analyzing the dataset resulting from the simulations.

\section{Results and Discussion}

The temporal variations of the aerosol optical depth, measured by the AERONET photometer, and the global solar radiation, measured by the SONDA pyranometer, during the years of 2013 and 2014 are presented in Fig. 1. This figure shows only the $A O D$ values associated with the $500 \mathrm{~nm}$, since this is the wavelength with higher solar irradiance among the eight measured spectral bands according to ASTM G173-03 (2012). The $A O D$ associated to the other wavelengths presented similar behavior.

The average trends of aerosol optical depth and global solar radiation values present similarity regarding their interannual variability (Fig. 1). As verified by Krzyścin and Puchalski (1998) in Belsk (Poland) during four

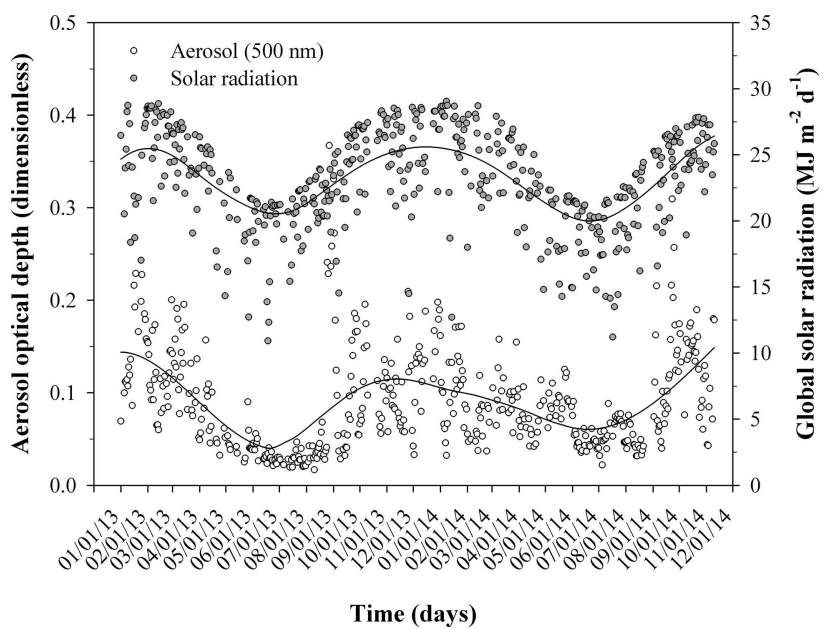

Figure 1 - Variations of aerosol optical depth and global solar radiation during the years of 2013 and 2014 in the Brazilian Northeast semiarid region. The continuous lines represent the average data trends. consecutive years (1993-1996), this trend reveals an apparent proportionality between $A O D$ and $R_{\text {global }}$. However, from the physical point of view, larger quantities of aerosol particles suspended in atmosphere imply in lower values of global solar radiation intercepted by the terrestrial surface due to the energy absorption process by the aerosols in discrete wavelengths (Novais et al., 2017; Steiner et al., 2013). This implies in an inversely proportional relationship. On the other hand, the aerosols can increase the diffuse radiation due to the intensification of solar radiation scattering (Gu et al., 2002; Murthy et al., 2014).

The multivariate model developed by the partial least squares regression technique for estimating the global solar radiation on terrestrial surface as function of the aerosol optical depths and the extraterrestrial solar radiation is represented by the equation:

$$
\begin{array}{r}
R_{\text {global }}=115.817 A O D_{380}-203.690 A O D_{440}+ \\
0.237 A O D_{500}+177.767 A O D_{675}-80.398 A O D_{870} \\
-2.232 A O D_{940}-8.839 A O D_{1020}+0.716 R_{0}+4.3369
\end{array}
$$

where $R_{\text {global }}$ is the global solar radiation $\left(\mathrm{MJ} \mathrm{m}^{-2} \mathrm{~d}^{-1}\right)$, $A O D$ is the aerosol optical depth at wavelengths of 380 , $440,500,675,870,940$, and $1020 \mathrm{~nm}$ (dimensionless), and $R_{0}$ is the extraterrestrial solar radiation $\left(\mathrm{MJ} \mathrm{m}^{-2} \mathrm{~d}^{-1}\right)$.

As expected, for similar $R_{0}$ and different $A O D$ values, the multivariate model resulted in smaller $R_{\text {global }}$ values when larger aerosol optical depths were used as input data.

Seven latent variables were selected during the model calibration with cross-validation, since this number minimized the root mean square error and maximized the coefficient of correlation. The use of more than seven latent variables for global solar radiation resulted in an over-fitting, characterized by a slight divergence in the downward trend of the root mean square error. These results agree with Cozzolino et al. (2011) who affirmed that if more than optimum number of latent variables is used, the solution can become over-fitted and the model will be very dependent on the dataset, giving poor prediction results. On the other hand, as noted by Steidle Neto et al. (2017), using less than the optimum number of latent variables will cause under-fitting and the model will not be accurate enough to capture the variability in the data.

Figure 2 shows the correlations between the $R_{\text {global }}$ values and those predicted by the multivariate model after the external validation. The scatter plot resulted in good agreement between reference and estimated values, indicating that the predictive capability and accuracy of the proposed model was satisfactory. These results were confirmed by the mean absolute error, which indicated that the values estimated by the multivariate model and those measured by the pyranometer differ on average by 


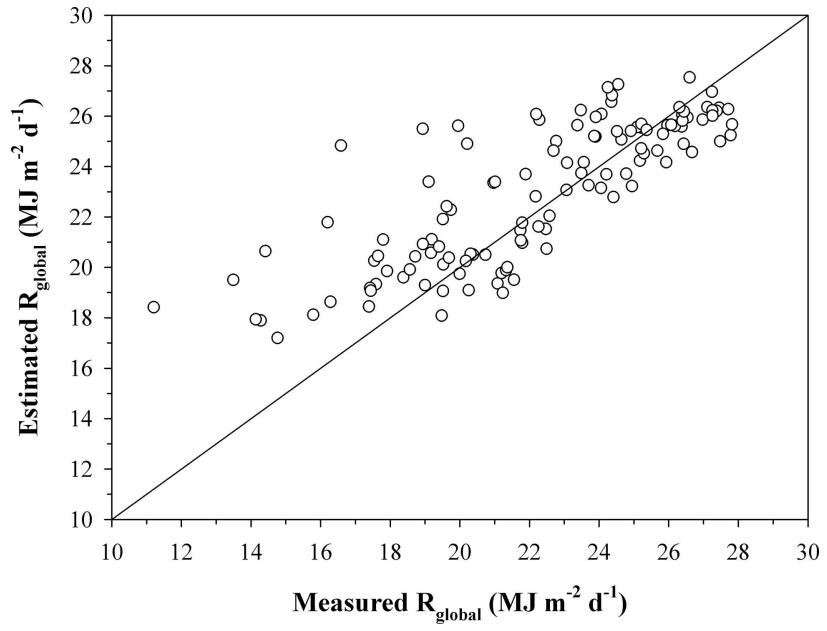

Figure 2 - External validation of the multivariate model for estimating the global solar radiation in the terrestrial surface in the Brazilian Northeast semiarid region.

$1.705 \mathrm{MJ} \mathrm{m}^{-2} \mathrm{~d}^{-1}$. This is a low value when considering the variation range of the global solar radiation (11.210 $27.820 \mathrm{MJ} \mathrm{m}^{-2} \mathrm{~d}^{-1}$ ) observed in this study and suggests that the proposed model is accurate. The predictive capacity of the model was also confirmed by the small mean relative error $(8.79 \%)$ and the mean bias error, whose positive value indicated that the multivariate model overestimated the global solar radiation on average by $0.820 \mathrm{MJ} \mathrm{m}^{-2} \mathrm{~d}^{-1}$. Further, the root mean square error was little expressive $\left(2.307 \mathrm{MJ} \mathrm{m}^{-2} \mathrm{~d}^{-1}\right)$ when compared to the studied global solar radiation range, reinforcing the model precision and reliability. Finally, the coefficient of correlation was 0.813 , indicating that $81.3 \%$ of the measured values were properly represented by the multivariate model.

The deviations associated with the $E T_{0}$ estimates (17 scenarios) due to the influence of aerosol optical depth changes are presented in Fig. 3.

The percentage frequencies of occurring deviations in the $E T_{0}$ estimates were distributed in 10 classes and are shown in Fig. 4.

Most of $E T_{0}$ deviations (57\%) were concentrated in positive classes, which correspond to $E T_{0}$ values larger than the original ones for each scenario (right half of Fig. 4). The other deviations (43\%) corresponded to the $E T_{0}$ values smaller than the original ones and were associated to the negative classes (left half of Fig. 4). This indicates that there were more occurrences of smaller aerosol optical depths than those initially associated with each scenario in the evaluated dataset. That is, for a same extraterrestrial solar radiation, smaller aerosol optical depths are associated with smaller absorptions of radiation, and with larger $R_{\text {global }}$ and $E T_{0}$ values. To the contrary, larger aerosol optical depths will result in smaller

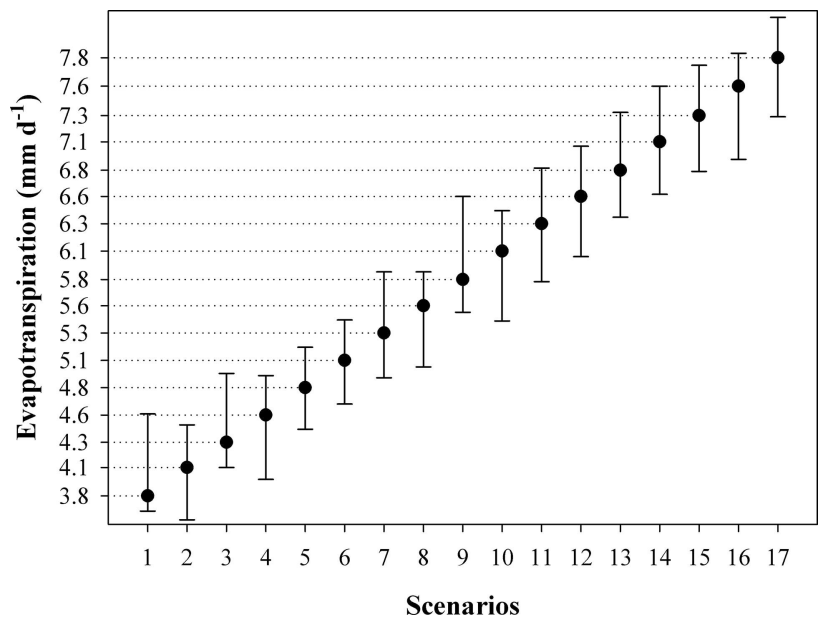

Figure 3 - Variations of minimal and maximum deviations for $\mathrm{ET}_{0}$ scenarios, caused by the influence of atmospheric aerosols during the years of 2013 and 1024 in the Brazilian Northeast semiarid region.

$R_{\text {global }}$ and $E T_{0}$, when considering a same extraterrestrial solar radiation.

Additionally, higher deviation concentrations were verified in the classes from 0 to $\pm 2 \%$ and from \pm 2 to $\pm 4 \%$ (Fig. 4), indicating that for most simulations in Petrolina (2013-2014 biennium) the changes in aerosol optical depths did not result in expressive effects on the $E T_{0}$. However, when considering all the other classes together, the frequency of deviations totaled approximately $27 \%$, which may result in relevant consequences on the irrigation management, water balance, agroclimatic zoning, among other activities based on the $E T_{0}$ estimates.

Steiner et al. (2013) investigated the impact of aerosols over six sites of United States of America with different land-cover types, reporting that high $A O D$ reduced latent heat flux by $9 \%-30 \%$. Murthy et al. (2014) also evaluated the effect of aerosols on evapotranspiration over a station at the India Southeast for the year 2011 and verified reductions in the latent heat flux of $14 \%$. The possible reasons for the results discussed by these authors are that while the aerosols reduce direct radiation, an increase in diffuse radiation occurs by scattering aerosols, as mentioned previously. This could lead to more photosynthesis and increases the transpiration that partially offsets evaporation decrease, resulting in relatively less reduction in latent heat flux. The increase in photosynthetic process occurs due to the diffuse radiation better penetrates the vegetative canopy, reaching the shaded leaves.

The results of this research reveal the magnitude of the atmospheric aerosol effects on reference evapotranspiration in the Brazilian Northeast semiarid region. Considering that one of the main anthropogenic sources of atmospheric aerosol rise in Brazil and in other countries is the soot from biomass burning and that it has steadily increasing along the years, it is important that new studies 


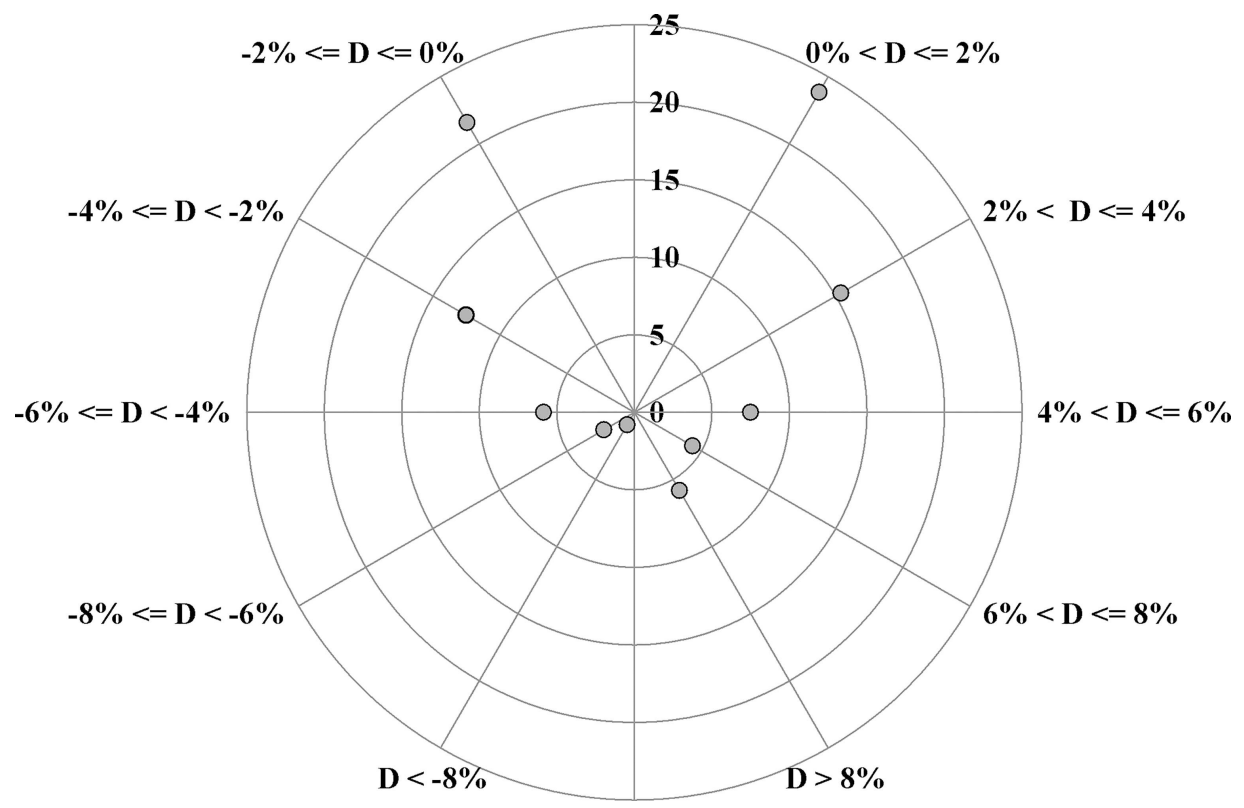

Figure 4 - Percentage frequencies of deviations (D) in the $\mathrm{ET}_{0}$ estimates (radius) and their occurrence classes (angles) due to the presence of atmospheric aerosols in the Brazilian Northeast semiarid region.

are carried out to better evaluate the effects of aerosols by using the methodology proposed in this study in different regions and with larger $A O D$ historical series. In this context, the most significant barrier is the availability of continuous series of aerosol optical depths with consistency and quality assured by AERONET (processing level 2.0) for the new study location, as well as the existence of a meteorological station located next to the AERONET photometer to register and measure the air temperature, air relative humidity, wind speed, pluvial precipitation, and global solar radiation.

\section{Conclusions}

For a same extraterrestrial solar radiation, larger aerosol optical depths can decrease the reference evapotranspiration, while ticker aerosol optical depths tend to increase reference evapotranspiration due to the less radiation absorption. This influence tends to change the reference evapotranspiration in around $\pm 4 \%$ in the semiarid region of the Brazilian Northeast. Nevertheless, more expressive changes can also occur with small frequency, resulting in relevant consequences on the irrigation management, water balance, agroclimatic zoning, among other activities based on the reference evapotranspiration estimates.

The proposed methodology allows that new models for estimating the global solar radiation from aerosol optical depths are calibrated and validated with the purpose of quantifying the aerosol impacts on evapotranspiration in other sites around the world.

\section{Acknowledgments}

The authors are grateful to the International AERONET Federation and the principal investigator Ph.D. Enio Bueno Perreira for their efforts in establishing and maintaining Petrolina station. Additionally, we would like to thank the Brazilian network of stations from the National Organization System of Environmental Data (Sistema Nacional de Organização de Dados Ambientais SONDA) of the Earth System Science Center (Centro de Ciência do Sistema Terrestre - CCST) which belongs to the Brazilian National Institute for Space Research (Instituto Nacional de Pesquisas Espaciais - INPE).

\section{References}

AGELET, L.E.; HURBURGH JR., C.R. Limitations and current applications of near infrared spectroscopy for single seed analysis. Talanta, v. 121, p. 288-299, 2014.

ALLEN, R.G.; PEREIRA, L.S.; RAES, D.; SMITH., M. Crop evapotranspiration: guidelines for computing crop water requirements. Irrigation and Drainage Paper 56. Rome, Italy: Food and Agriculture Organization of the United Nations (FAO), p. 300, 1998.

ALLEN, R.G. REF-ET: reference evapotranspiration calculation software for FAO and ASCE standardized equations. Version 3.1.15. University of Idaho, Department of Water Resources, p. 91, 2013.

ALVARES, C.A.; STAPE, J.L.; SENTELHAS, P.C.; MORAES GONÇALVES, J.L.; SPAROVEK, G. Köppen's climate classification map for Brazil. Meteorologische Zeitschrift, v. 22 , n. 6 , p. $711-728,2013$. 
ASTM G173-03. Standard tables for reference solar spectral irradiance at air mass 1.5: direct normal and hemispherical on 37 degree tilted surface. West Conshohocken, USA: American Society for Testing and Materials, 2012.

CHE, H.; WANG, Y.; SUN, J. Aerosol optical properties at Mt. Waliguan observatory, China. Atmospheric Environment, v. 45 , p. $6004-6009,2011$

COZZOLINO, D.; CYNKAR, W.U.; SHAH, N.; SMITH, P. Multivariate data analysis applied to spectroscopy: potential application to juice and fruit quality. Food Research International, v. 44, p. 1888-1896, 2011.

FORINA, M.; LANTERI, S.; CERRATO OLIVEROS, M.C.; PIZARRO MILLAN, C. Selection of useful predictors in multivariate calibration. Analytical and Bioanalytical Chemistry, v. 380, p. 397-418, 2004.

GU, L.; BALDOCCHI, D.D.; VERMA, S.B.; BLACK, T.A.; VESALA, T.; et al. Advantages of diffuse radiation for terrestrial ecosystem productivity. Journal of Geophysical Research, v. 107, ACL 2-1-ACL 2-23, 2002.

HOLBEN, B.N.; ECK, T.F.; SLUTSKER, I.; TANRÉ, D.; BUIS, J.P.; et al. AERONET - a federated instrument network and data archive for aerosol characterization. Remote Sensing of Environment, v. 66, p. 1-16, 1998.

HOLBEN, B.N.; TANRÉ, D.; SMIRNOV, A.; ECK, T.F.; SLUTSKER, I.; et al. An emerging ground-based aerosol climatology: aerosol optical depth from AERONET. Journal of Geophysical Research, v. 106, n. D11, p. 1206712097, 2001.

IPCC. The physical science basis: contribution of working group I to the fourth assessment report of the intergovernmental panel on climate change, Chapter 2, 2007.

JHA, S.N. Nondestructive evaluation of food quality: theory and practice. New York, USA: Springer Science \& Business Media, p. 288, 2010.

KRZYŚCIN, J.W.; PUCHALSKI, S. Aerosol impact on the surface UV radiation from the ground-based measurements taken at Belsk, Poland, 1980-1996. Journal of Geophysical Research, v. 103, n. D13, p. 16175-16181, 1998.

KUMAR, K.R.; SIVAKUMAR, V.; REDDY, R.R.; GOPAL, K. R.; ADESINA, A.J. Inferring wavelength dependence of AOD and Ångström exponent over a sub-tropical station in South Africa using AERONET data: influence of meteorology, long-range transport and curvature effect. Science of the Total Environment, v. 461-462, p. 397-408, 2013.

LIEPERT, B.; TEGEN, I. Multidecadal solar radiation trends in the United States and Germany and direct tropospheric aerosol forcing. Journal of Geophysical Research, v. 107, AAC 7-1-AAC 7-15, 2002.

MARTIN, S.T.; ANDREAE, M.O.; ARTAXO, P.; BAUMGARDNER, D.; CHEN, Q.; et al. Sources and properties of Amazonian aerosol particles. Reviews of Geophysics, v. 48, n. RG2002, p. 1-42, 2010.
MURTHY, B.S.; LATHA, R.; KUMAR, M.; MAHANTI, N.C. Effect of aerosols on evapo-transpiration. Atmospheric Environment, v. 89, p. 109-118, 2014.

NOVAIS, J.W.Z.; SANTANNA, F.B.; ARRUDA, P.H.Z.; PEREIRA, O.A.; DUTRA, R. Relação entre profundidade óptica de aerossóis e radiação fotossinteticamente ativa e global no Cerrado Mato-Grossense. Revista Estudo \& Debate, v. 24, n. 1, p. 153-167, 2017.

PAIXÃO, M.M.A. Propriedades ópticas de aerossóis naturais e de queimadas da Amazônia. Dissertação. São Paulo: Universidade de São Paulo, p. 120, 2011.

SIVAKUMAR, V.; TESFAYE, M.; ALEMU, W.; SHARMA, A.; BOLLIG, C.; et al. Aerosol measurements over South Africa using satellite, sun-photometer and LIDAR. Advances in Geosciences, v.16, p. 253-262, 2010.

STEIDLE NETO, A.J.; BORGES JÚNIOR, J.C.F.; ANDRADE, C.L.T.; LOPES, D.C.; NASCIMENTO, P.T. Reference evapotranspiration estimates based on minimum meteorological variable requirements from historical weather data. Chilean Journal of Agricultural Research, v. 75, n. 3, p. 366-374, 2015.

STEIDLE NETO, A.J.; LOPES, D.C.; PINTO, F.A.C.; ZOLNIER, S. Vis/NIR spectroscopy and chemometrics for nondestructive estimation of water and chlorophyll status in sunflower leaves. Biosystems Engineering, v. 155, p. 124133, 2017.

STEINER, A.L.; MERMELSTEIN, D.; CHENG, S.J.; TWINE, T.E.; OLIPHANT, A. Observed impact of atmospheric aerosols on the surface energy budget. Earth Interactions, v. 17, n. 14, p. 1-22, 2013.

TRENBERTH, K.E.; FASULLO, J.T.; KIEHL, J. Earth's global energy budget. Bulletin of American Meteorology Society, v. 90, p. 311-323, 2009.

WANG, K.; DICKINSON, R.E.; LIANG, S. Observational evidence on the effects of clouds and aerosols on net ecosystem exchange and evapotranspiration. Geophysical Research Letters, v. 35, n. L10401, p. 1-5, 2008.

WANG, P.; CHE, H.; ZHANG, X.; SONG, Q.; WANG, Y.; et al. Aerosol optical properties of regional background atmosphere in Northeast China. Atmospheric Environment, v. 44, p. 4404-4412, 2010.

WOLD, S.; SJÖSTROM, M.; ERIKSSON, L. PLS-regression: a basic tool of chemometrics. Chemometrics and Intelligent Laboratory Systems, v. 58, p. 109-130, 2001.

YANG, J.M.; YANG, J.Y.; LIU, S.; HOOGENBOOM, G. An evaluation of the statistical methods for testing the performance of crop models with observed data. Agricultural Systems, v. 127, p. 81-89, 2014.

This is an Open Access article distributed under the terms of the Creative Commons Attribution Non-Commercial License which permits unrestricted non-commercial use, distribution, and reproduction in any medium provided the original work is properly cited. 